\title{
A diverse Upper Darriwilian radiolarian assemblage from the Shundy Formation of Kazakhstan: insights into late Middle Ordovician radiolarian biodiversity
}

\author{
LAUREN POUILLE ${ }^{1 *}$, TANIEL DANELIAN ${ }^{1} \&$ LEONID E. POPOV $^{2}$ \\ ${ }^{1}$ Department of Earth Sciences, University Lille 1, CNRS-UMR 8217 Géosystèmes, Cité Scientifique, SN5, 59655 Villeneuve d'Ascq, France \\ ${ }^{2}$ Department of Geology, National Museum of Wales, Cathays Park, Cardiff, CF10 3NP \\ *Corresponding author (e-mail: lauren.pouille@laposte.net)
}

\begin{abstract}
A diverse and well-preserved radiolarian assemblage was extracted from a carbonate sample of latest Darriwilian age from the Shundy Formation of the Aksuran Mountain (North Balkhash Region, Kazakhstan). The fauna is represented by 32 species or morphotypes which belong to nine genera, four families and two orders (Spumellaria and Entactinaria), including four new species described herein (Syntagentactinia? angulata n. sp. Pouille \& Danelian, Polyentactinia spinulenta $\mathrm{n}$. sp. Pouille \& Danelian, Haplotaeniatum circulus n. sp. Pouille \& Danelian and H.? giganteum n. sp. Pouille \& Danelian). Representatives of the family Inaniguttidae are particularly abundant, representing c. $70 \%$ of the studied assemblage, especially genera Triplococcus and Inanihella that dominate the assemblage. Although the studied fauna contains both of the characteristic species and most of the genera of the previously defined Haplentactinia juncta-Inanigutta unica assemblage, differences in the assemblage structure are striking. The studied fauna also establishes that the two characteristic species of the Inanihella bakanasensis-Triplococcus akzhala assemblage are not restricted to the early-mid-Darriwilian, but their age range also extends to the latest Darriwilian.
\end{abstract}

KEYWORDS: Radiolaria, taxonomy, palaeobiodiversity, Darriwilian, Ordovician, Kazakhstan

\section{INTRODUCTION}

In spite of the major progress achieved recently in understanding the 'Great Ordovician Biodiversification Event' (Webby et al., 2004; Servais et al., 2010), our knowledge of the biodiversity and diversification dynamics of some biotic groups is still very fragmentary. This is particularly true for polycystine Radiolaria, a major component of the oceanic heterotrophic plankton in Early Palaeozoic marine ecosystems, from which only a few radiolarian assemblages have so far been recognized (Noble \& Danelian, 2004; Maletz, 2007; Noble \& Webby, 2009; Danelian et al., 2013).

Middle Ordovician radiolarian faunas recovered from carbonate sequences in Kazakhstan are of major significance for advancing our understanding of Ordovician Radiolarian biodiversity. Middle Ordovician radiolarian assemblages are also known from siliceous sequences of Lower Palaeozoic orogenic belts (i.e. Scotland: Danelian \& Clarkson, 1998; Danelian \& Floyd, 2001; Kyrgyzstan: Danelian et al., 2011; China: Buckman \& Aitchison, 2001), but they are less well preserved, due to differences in taphonomic history and laboratory processing.

To date in Kazakhstan, three distinct Ordovician assemblages have been recognized from a restricted number of localities, dispersed around Lake Balkash (Nazarov, 1975, 1988; Nazarov et al., 1977; Nazarov \& Popov, 1980; Nazarov \& Ormiston, 1993; Danelian \& Popov, 2003), as follows (Fig. 1):

- The Inanihella bakanasensis-Triplococcus akzhala assemblage, described by Danelian \& Popov (2003) from sample 8807-A of the Akhzal Formation. This assemblage was initially considered as Floian in age, but later it was also recovered from the lower Darriwilian of Argentina (Maletz et al., 2009) and was considered as covering the upper Dapingian-lower Darriwilian interval (Maletz 2007, 2011).

- The Proventocitum procerulum assemblage was described by Nazarov \& Popov (1980) from the middle Darriwilian of Kazakhstan (sample 19, coming from the Kurchilik Formation).
It was also recorded from Spitsbergen (Fortey \& Holdsworth, 1971; Holdsworth, 1977; Maletz \& Bruton, 2008) and Scotland (Aitchison, 1998). The Proventocitum procerulum assemblage was at first thought to range from late Floian to early Darriwilian (Nazarov \& Popov, 1980; Danelian \& Popov, 2003), but it is now referred to as Darriwilian in age (Maletz, 2007; Maletz \& Bruton, 2008).

- The Haplentactinia juncta-Inanigutta unica assemblage was described by Nazarov \& Popov (1980) from sample 553a, coming from the lower part of the Bestomak Formation (Chingiz Range). The radiolarian assemblage co-occurs with a diverse trilobite and brachiopod assemblage suggesting a latest Darriwilian-earliest Sandbian age (Nazarov \& Popov, 1980). The radiolarian-bearing carbonate level is overlain in this section by black shales with graptolites of the Nemagraptus gracilis Biozone (lowermost Sandbian).

A new, diverse and rather well-preserved radiolarian assemblage from the uppermost Darriwilian in Kazakhstan is presented here. The radiolarian assemblage is dominated by members of the family Inaniguttidae, represented by five genera (Triplococcus, Inanihella, Inanigutta, Inanibigutta and Kalimnasphaera) and 14 species, which have been documented and discussed recently by Pouille et al. (2013), together with several co-occurring trilobites. This paper focuses essentially on the taxonomic study of the rest of the fauna that includes 18 species and morphotypes that belong to the families Haplentactiniidae, Polyentactinidae and Haplotaeniatidae, including four new species. It allows considerable improvement to our understanding of the radiolarian palaeobiodiversity during the late Darriwilian, a critical interval in the context of the Ordovician diversification (Servais et al., 2008, 2010).

\section{STRATIGRAPHIC SETTING AND AGE}

The radiolarian-bearing sample was collected from locality 112, about $1100 \mathrm{~m} \mathrm{WSW}$ of the Aksuran Mountain (NW of Lake 


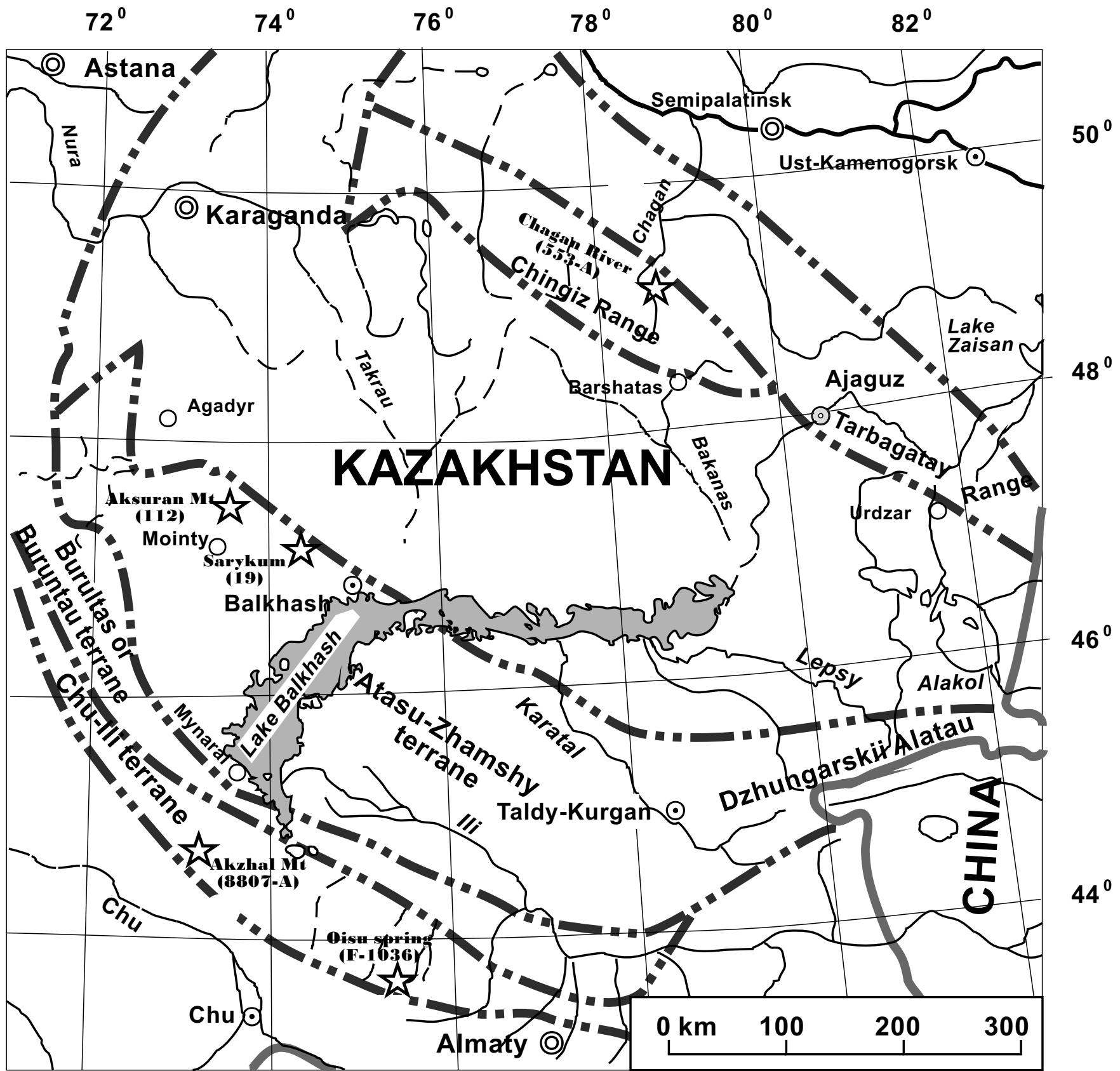

Fig. 1. Schematic map indicating the location of Ordovician radiolarian-bearing samples from the Aksuran Mts, Kazakhstan discussed in this study (including sample 112). Boundaries limiting the main tectonic terranes present in the area are shown (modified after Danelian \& Popov, 2003).

Balkhash) in the Atasu-Zhamshy Region $\left(47^{\circ} 32^{\prime} 40.77^{\prime \prime} \mathrm{C}\right.$, $73^{\circ} 2^{\prime} 47.34^{\prime \prime E}$; Fig. 1). It was sampled from the middle part of the Shundy Formation, which consists of deep-water, black or dark grey bedded limestones intercalated with thin dark grey cherts, which probably accumulated at the base of a slope of a passive continental margin of a Lower Palaeozoic microplate. Details about its geological and stratigraphic setting are provided in Pouille et al. (2013).

Graptolites, identified by Tsai (in Apollonov et al., 1990) as Hustedograptus ex gr. teretiusculus, occurring in the same stratigraphic level as the radiolarian-bearing sample 112 suggest a latest Darriwilian age. The trilobites (Endymionia semielliptica, Nambeetella? sp. and Porterfieldia sp. aff. P. delicata) found associated with the sample confirm this age (Pouille et al., 2013). Moreover, two radiolarian genera commonly present in sample 112 (Syntagentactinia and Kalimnasphaera) are known to first occur in the Haplentactinia juncta-Inanigutta unica assemblage which can be best correlated with the uppermost Darriwilian-lowermost Sandbian (see, for example, the discussion in Nazarov \& Ormiston, 1993; Danelian \& Popov, 2003; Maletz, 2011). Our assemblage also contains Haplentactinia juncta, one of the characteristic species of the Haplentactinia juncta-Inanigutta unica assemblage. 




Fig. 2. Pie diagram showing the percentage relative abundance of radiolarian genera composing the assemblage of sample 112 .

\section{MATERIAL AND METHODS}

Radiolarians were extracted from a black to dark grey micritic limestone sample after a standard treatment with $30 \%$ diluted acetic acid. Taxonomic study of this assemblage was made on the basis of SEM observation on over 450 specimens. This newly discovered assemblage is highly diverse, with a good state of preservation. All the types described here are housed in the public palaeontological collections of the Earth Sciences Department (SN5) of the University Lille 1 (France).

\section{FAUNAL COMPOSITION}

The identified radiolarian assemblage consists of four families (Inaniguttidae, Haplotaeniatidae, Haplentactiniidae and Polyentactiniidae), nine genera (Inanihella, Triplococcus, Inanigutta, Inanibigutta, Kalimnasphaera, Haplotaeniatum, Syntagentactinia, Polyentactinia and Haplentactinia) and 32 species or morphotypes. The radiolarians are dominated by inaniguttid species, which represent over two-thirds of the assemblage (69\%; Fig. 2); they are represented by 5 genera (Inanihella, Triplococcus, Inanigutta, Inanibigutta and Kalimnasphaera) and 14 species. The rest is composed of Haplotaeniatum (15\%), Syntagentactinia (13\%), Polyentactinia (3\%) and rare Haplentactinia (Fig. 2). The family Inaniguttidae is dominated by the genus Triplococcus that represents half of the Inaniguttidae (54\%) and $37 \%$ of the whole assemblage (Fig. 2). Genus Triplococcus is represented in proportion of $89 \%$ by two species: T. aksuranensis (49\%) and T. akzhala $(40 \%)$ which are predominant, representing one-third $(33 \%)$ of the assemblage. Genus Inanihella is dominated by 3 species (I. hirta, I. bakanasensis and $I$. sp. B) and represents $32 \%$ of the Inaniguttidae and $22 \%$ of the whole assemblage. The rest of the family Inaniguttidae is composed of Inanibigutta (8\%), Inanigutta (4\%) and Kalimnasphaera (2\%).
The Haplotaeniatidae are composed, for a large part, of $H$. sp. cf. H. tegimentum, representing half of the Haplotaeniatum present in the sample (54\%), H. nobleae (24\%) and H. circulus $(10 \%)$. The Haplentactinidae are composed of $98 \%$ of representatives of the genus Syntagentactinia, dominated by S.? sp. cf. S.excelsa (47\%). Genus Haplentactinia is represented by only one species: H. juncta, which represents $2 \%$ of the Haplentactinidae. The family Polyentactinidae is dominated $(73 \%)$ by the species $P$. spinulenta.

SYSTEMATIC PALAEONTOLOGY (L. Pouille \& T. Danelian)

Order Entactinaria Kozur \& Mostler, 1982

Family Haplentactiniidae Nazarov in Nazarov \& Popov (1980)

Genus Syntagentactinia Nazarov in Nazarov \& Popov (1980)

Type species. Syntagentactinia biocculosa Nazarov in Nazarov \& Popov (1980).

Syntagentactinia biocculosa Nazarov in Nazarov \& Popov (1980) (P1. 1, figs 5-7)

1980 Syntagentactinia biocculosa Nazarov in Nazarov \& Popov: 56; pl. 12, figs $1-3$.

Material. Five specimens.

Description. Internal structure consists of a five- to six-rayed primary spicule incorporated in a small latticed inner shell. The primary rays of the initial spicule are prolonged outside into long rod-like spines (up to $200 \mu \mathrm{m}$ ). These primary spines can be straight or slightly curved on their proximal part. A small internal cavity with an irregular outline separates the inner shell from the outer shell. The outer shell structure consists of three to four spongy shell layers of irregular outline and that are closely interconnected by numerous 
radial beams in a very complex three-dimensional arrangement. The different spongy layers of the shells are hardly distinct. The outer shell is mostly spherical (rarely sub-spherical) and displays a spongy external aspect. Inside the inner cavity, rare apophyses can branch from the primary rays to join the inner shell surface.

Dimensions $(\mu \mathrm{m})$. Diameter of the outer shell: $232-277$; of the inner shell: 76-98; length of primary spines: 120-220; thickness of the outer structure: $80-110$.

Remarks. The skeleton structure and dimensions of S. biocculosa are very close to those of $S$.? sp. cf. $S$. excelsa Nazarov \& Ormiston. However, it differs from it in possessing six long, robust rod-like spines, a less loose latticed inner shell and in having a less distinct inner cavity. It also differs from $S$. pauca Nazarov in possessing a thick multi-layered spongy outer shell and in its larger size. It also differs from $S$. afflicta Nazarov \& Ormiston in the absence of internal half-closed shells, in the larger size of its inner shell (as compared with the material of Nazarov \& Ormiston, 1993) and in its smaller size (for the material illustrated by Kurihara \& Sashida, 2000).

Syntagentactinia? sp. cf. S. excelsa Nazarov \& Ormiston, 1993 (P1. 1. figs 1-4)

cf. 1993 Syntagentactinia excelsa Nazarov \& Ormiston: 40; pl. 6, figs 13-14.

cf. 2000 Syntagentactinia excelsa Nazarov \& Ormiston; Kurihara \& Sashida: 153; figs 7.19, 7.20; 8.1-8.7.

Material. 29 specimens.

Description. The inner framework consists of a distinct spherical to subspherical loosely latticed inner sphere, centrally or slightly eccentrically located inside the internal cavity. The outer shell consists of a thick spherical spongy meshwork formed of three to four latticed shell layers closely interconnected in a three-dimensional way by many radial beams. In some cases it can be very difficult to distinguish the different shell layers, and the outer shell forms a very complex sponge-like ball. The inner shell is connected to the outer shells by a few beams. Primary spines are very thin, weakly developed and commonly not visible outside. The innermost structure is not preserved in our material.

Dimensions $(\mu \mathrm{m})$. Diameter of the cortical shell: 231-283; of the inner shell: 76-97; Thickness of the outer shell: 45-75.

Remarks. This species differs from the other two Ordovician Syntagentactinia species described by Nazarov \& Popov (1980) ( $S$. biocculosa and S. pauca) in possessing a thick multi-layered spongy outer shell, in the absence of rod-like outer spines and in its larger size. Our specimens differ from $S$. excelsa as described by Nazarov \& Ormiston (1993) only in their inner shell dimensions (40-42 $\mu \mathrm{m}$ in Nazarov \& Ormiston's material), but correspond relatively well to the dimensions given by Kurihara \& Sashida $(2000 ; 40-90 \mu \mathrm{m})$. The species differs from $S$. afflicta that co-occurs with $S$. excelsa in the absence of long, robust, rod-like spines and in its internal half-closed shells.

Syntagentactinia? sp. aff. S. excelsa Nazarov \& Ormiston, 1993 (P1. 1. figs 8-11)

aff. 1993 Syntagentactinia excelsa Nazarov \& Ormiston: 40; pl. 6, figs $13-14$.

aff. 2000 Syntagentactinia excelsa Nazarov \& Ormiston; Kurihara \& Sashida: 153; figs 7.19, 7.20; 8.1-8.7.

Material. 7 specimens.

Description. Spherical radiolarian with an outer shell structure formed of two (rarely three) spongy shell layers closely interconnected by many radial beams and arranged in a thick spongy three-dimensional way. The thickness of the spongy meshwork is variable. The internal framework consists of a large latticed inner shell with well-defined pores located inside a small hollow cavity. Inner shell is connected to the outer shells by short beams. Six primary rays protrude radially as very thin and short rod-like outer spines outside the outer shells. Thin secondary spines are present on the surface of the outer shell. The innermost framework is broken in every specimen but primary rays have been observed to protrude inside the inner shell.

Dimensions $(\mu \mathrm{m})$. Diameter of the cortical shell: 260-330; of the inner shell: 100-120; thickness of the outer structure: 32-70.

Remarks. It differs from S.? sp. cf. S. excelsa and S. biocculosa in its larger size (see Table 1) and in possessing thin secondary spines on the surface of the outer shell. It differs from $S$. pauca in its thick spongy outer shell and its larger size.

\section{Syntagentactinia? angulata $\mathrm{n}$. sp. Pouille \& Danelian (Pl. 1, figs 12-14b)}

Derivation of name. From the Latin word 'angulatus' meaning angular, bony.

Diagnosis. A thick, dense and spongy outer shell, displaying a polygonal to quadrangular outline, bears six thick rod-like spines and encloses a much smaller latticed inner shell.

Holotype. Plate 1, figure 13 (USTL1142/048).

Paratype. Plate 1, figure 14 (USTL1142/058).

Material. 9 specimens.

Description. The internal framework consists of a six-rayed pointcentred (?) spicule from which six primary rays originate. Apophyses branch from the primary rays at a distance of about $20-40 \mu \mathrm{m}$ from

Explanation of Plate 1. Scanning electron micrographs of Entactinaria from sample 112 (Shundy Formation, North Balkhash Region, Kazakhstan). Scale bar $100 \mu \mathrm{m}$. figs 1-4. Syntagentactinia? sp. cf. S. excelsa Nazarov \& Ormiston; figs 5-7. Syntagentactinia biocculosa Nazarov in Nazarov \& Popov: 5, specimen displaying broken internal spicule. figs 8-11. Syntagentactinia? sp. aff. S. excelsa Nazarov \& Ormiston. figs 12-14b. Syntagentactinia? angulata Pouille \& Danelian nov. sp.: 13, holotype; 14a, paratype; 14b, magnified view of the paratype's internal structure displaying broken internal spicule and apophyses branching to form the innermost shell. figs 15-18. Syntagentactinia? sp. cf. S. biocculosa Nazarov in Nazarov \& Popov. fig. 19. Syntagentactinia? sp. A. 


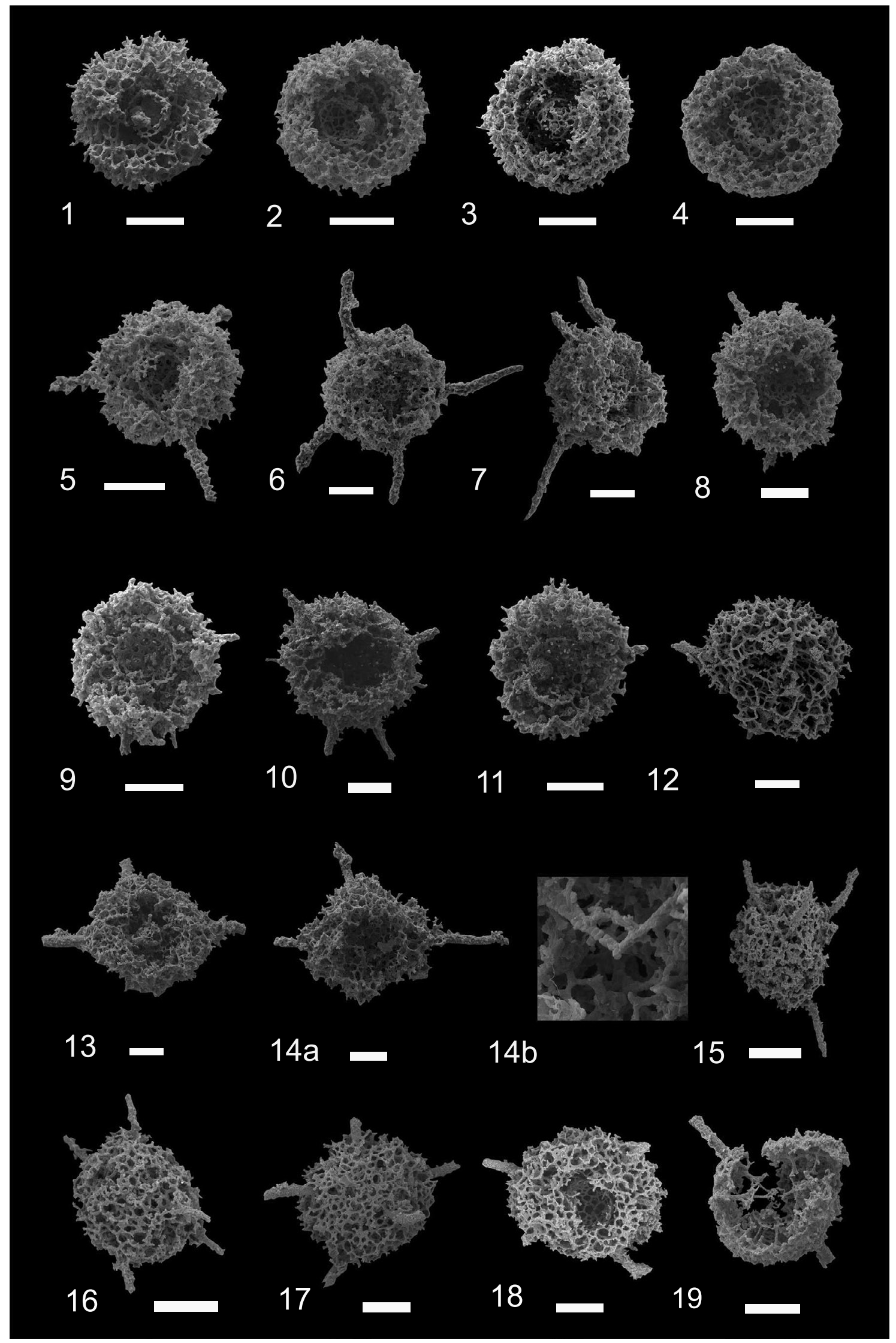


Table 1. Outer and inner shell diameter of $S$.? sp. aff. $S$. excelsa and related species.

\begin{tabular}{lcccc}
\hline in $\mu \mathrm{m})$ & S.? sp. aff. S. excelsa & S.? sp. cf. S. excelsa & S. biocculosa & S. pauca \\
\hline outer shell Ø & $260-330$ & $231-283$ & $175-277$ & $110-160$ \\
inner shell $\varnothing$ & $100-120$ & $76-97$ & $35-98$ & $50-82$ \\
\hline
\end{tabular}

Table 2. Outer shell diameter of $S$.? angulata and related species.

\begin{tabular}{cccccc}
\hline (in $\mu \mathrm{m})$ & S.? angulata & S. afflicta & S. excelsa & S. biocculosa & S. pauca \\
\hline outer shell $\varnothing$ & $346-400$ & $240-310$ & $234-277$ & $175-225$ & $110-160$ \\
\hline
\end{tabular}

the spicule centre to form a small irregularly latticed inner shell, which is unevenly porous and located inside a hollow cavity. The latter is very irregular in outline and clearly separates the inner and outer shells. The outer shell is formed of different groups of apophyses that branch from the primary rays to form a very thick, irregular and dense spongy meshwork (up to $130 \mu \mathrm{m}$ thick). The outer shell displays a polygonal to quadrangular outline. Primary rays are disposed in the three rectangular axes and prolonged into thick rod-like outer spines.

Dimensions $(\mu \mathrm{m})$. Diameter of the cortical shell: $346-400$; of the inner shell: $64-85$; length of primary spines: up to 200 .

Remarks. Due to its small size, the inner shell surrounding the primary spicule can be mistaken for a microsphere on unbroken specimens. The primary spicule appears to be point-centred; however, it could also be interpreted as a broken bar-centred spicule, which explains the doubtful generic assignment. This species differs from other species of the genus Syntagentactinia in the polygonal to quadrangular outline of its outer shell, its wide inner cavity, its thick and complex three-dimensional nonlayered meshwork and its much larger size (see Table 2).

\section{Syntagentactinia? sp. cf. S. biocculosa Nazarov in Nazarov \& Popov, 1980 \\ (P1. 1, figs 15-18)}

cf. 1980 Syntagentactinia biocculosa Nazarov in Nazarov \& Popov: 56; pl. 12, figs 1-3.

Material. 10 specimens.

Description. The spongy outer shell displays an ovoid shape with six primary spines. Two spines are located on the margin of one pole of the shell. The four other horn-like spines are situated on the opposite pole of the shell and are curved inwardly. The outer shell consists of a thick, multi-layered, three-dimensional meshwork. The inner framework consists of a latticed inner shell. The innermost part of the framework is unknown.

Dimensions $(\mu \mathrm{m})$. Diameter of the outer shell: 190-318; diameter of the inner shell: $117-134$; length of the outer spines: up to 150 .
Remarks. It differs from other Syntagentactinia in its ovoid shape, the peculiar position of its primary spines and in the large size of its inner shell.

$$
\begin{gathered}
\text { Syntagentactinia? sp. A } \\
\text { (Pl. 1, fig. 19) }
\end{gathered}
$$

Material. 1 specimen.

Description. This morphotype displays a primary spicule located inside a very small sphere surrounded by an inner and an outer shell. Six or more primary rays originate from the primary spicule aligned with thick rod-like external spines. Numerous beams connect the latticed inner shell with the outer shell. The outer framework consists of two latticed shell layers closely interconnected in a three-dimensional arrangement. The outermost shell layer displays a thick spongy aspect.

Dimensions $(\boldsymbol{\mu m})$. Diameter of the innermost sphere: 33-38; of the inner shell: 91-98; of the outer shell: 229-238; length of the outer spines: up to 95 ; thickness of the outer shell wall: 33 .

Remarks. The small sphere inside the inner shell can be distinguished from a microsphere only by the presence of primary rays protruding inside it. As the primary spicule is broken it is difficult to know the exact number of primary rays that originated from it. This morphotype differs from all other species of Syntagentactinia in its regular outline, the presence of a very small sphere surrounding the primary spicule and the presence of numerous beams connecting the inner with the outer shells. It also differs from all the species described in this paper in possessing a much thinner outer shell wall.

Genus Haplentactinia Foreman, 1963

Type species. Haplentactinia rhinophyusa (Foreman, 1963).

Haplentactinia juncta Nazarov, 1975

(Pl. 2, fig. 1)

1975 Haplentactinia juncta Nazarov: 58; pl. 20, fig. 5, 6.

1980 Haplentactinia juncta Nazarov; Nazarov and Popov: 53; pl. 4, fig. 2; pl. 6, figs 3-5.

Explanation of Plate 2. Scanning electron micrographs of Entactinaria from sample 112 (Shundy Formation, North Balkhash Region, Kazakhstan). Scale bar $100 \mu \mathrm{m}$. fig. 1. Haplentactinia juncta Nazarov. figs 2-8. Polyentactinia spinulenta n. sp. Danelian \& Pouille: 7, holotype; 5a, 6, paratypes; $\mathbf{5 b}, \mathbf{6 b}$, magnified view of paratypes displaying the primary spicule and the median bar. fig. 9. Polyentactinia sp. cf. P. spinulenta Danelian \& Pouille. figs 10a-b. Polyentactinia sp. A. figs 11a-c. Polyentactinia sp. B: 11c, magnified view of the internal spicule. 


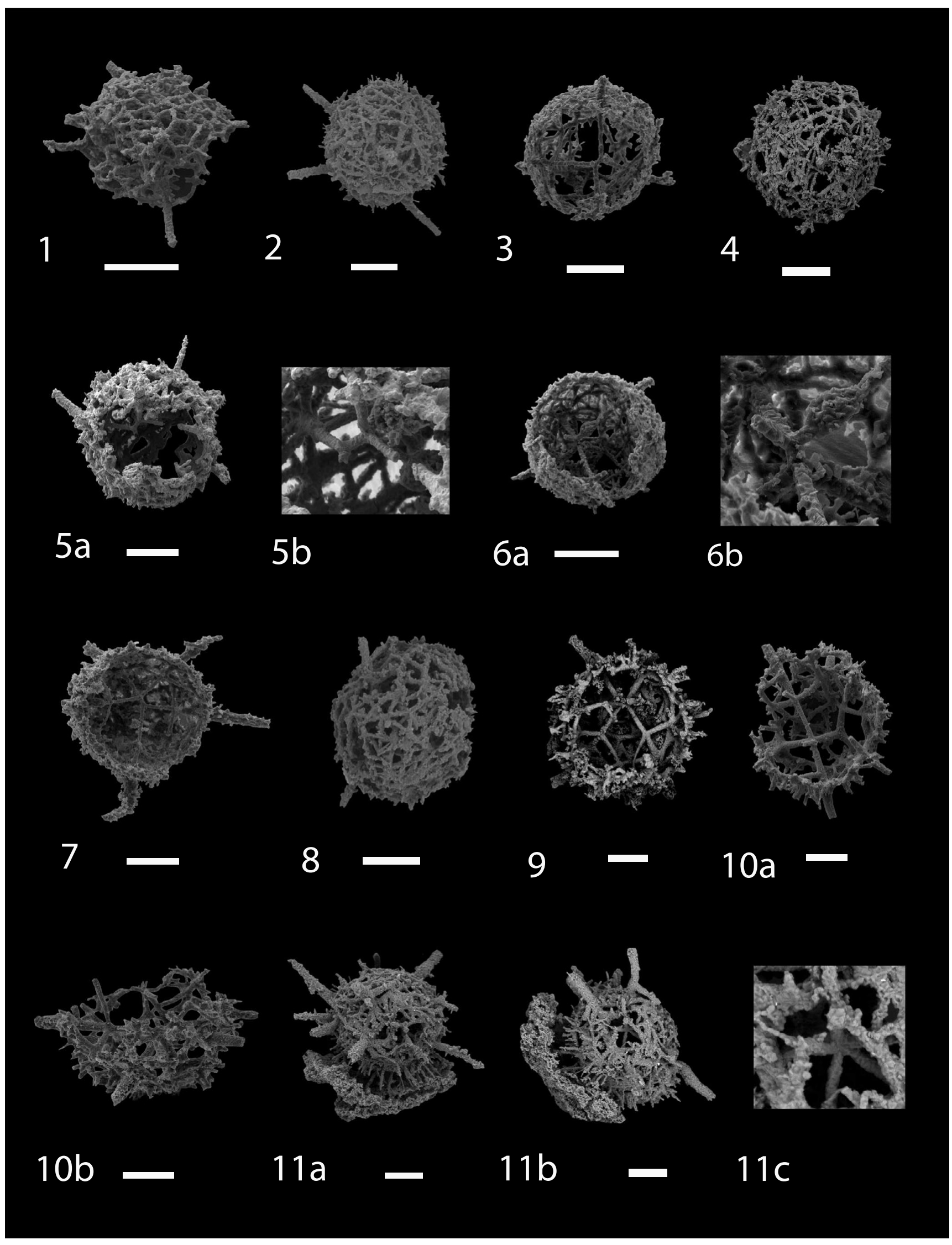


1988 Haplentactinia juncta Nazarov; Nazarov: pl. 10, fig. 4. 1994 Haplentactinia? juncta Nazarov; Gorka: 174; pl. 2, figs E, F.

Material. 1 specimen.

Dimensions $(\mu \mathrm{m})$. Diameter of the shell: 177-205; width of the meshes: $20-45$, length of the spines (from median bar): up to $150 \mu \mathrm{m}$.

Remarks. This species differs from $H$. armillata in its wider and more loosely constructed mesh, smaller size (shell Ø: 320-400 $\mu \mathrm{m}$ in $H$. armillata) and absence of a bifurcated primary spine. It also differs from $H$. infida and $H$. baltica in its more rounded outline. In addition, $H$. infida differs from $H$. juncta in possessing one spine considerably larger than the others and in having apophyses on this spine located closer to the inner spicule, whereas other apophyses are at equal distance from it.

Family Polyentactiniidae Nazarov, 1975

Genus Polyentactinia Foreman, 1963

Type species. Polyentactinia craticulata Foreman 1963.

Polyentactinia spinulenta n. sp. Pouille \& Danelian (P1. 2, figs 2-8)

Derivation of name. From the Latin word 'spinulentus' meaning thorny.

Diagnosis. A single spherical outer shell displaying a latticed meshwork of interwoven bars, bearing 6 rod-like outer spines, which originate from the primary rays of a short median bar located eccentrically in the internal part of the shell.

Holotype. Plate 2, figure 7 (USTL1140/008).

Paratypes. Plate 2, figure 5a (USTL1140/074); Plate 2, figure 6a (USTL1142/068).

Material. 11 specimens.

Description. Internal framework consists of a primary spicule formed of a short median bar $(10-15 \mu \mathrm{m})$ from which six primary rays originate. The median bar is eccentrically located in the spherical skeleton and it may often appear point-centred depending on its orientation. The six primary rays continue outside the spherical shell as rod-like outer spines that can be straight or slightly curved. They bear a verticil of two perpendicular whorled rays that originate at the level of the cortical shell with which they are connected to the spherical skeleton. The shell is formed from a latticed meshwork with angular meshes formed from interwoven bars of various thicknesses. On well-preserved specimens numerous small simple or bifurcated spinules are present on the shell surface.

Dimensions $(\mu \mathrm{m})$. Diameter of the shell: 227-305 (average, 262284 ); length of primary spines: up to 120 ; length of the median bar: $10-15$; thickness of the inner elements of the skeleton: up to 10 .

Remarks. This species differs from Astroentactinia in the absence of characteristic pores and of any conical secondary spines on its cortical shell. Its internal frame and its shell structure suggest an assignment to Polyentactinia. P. spinulenta differs from P. offerta Nazarov (an upper Darriwilian species described from the Haplentactinia juncta-Inanigutta unica assemblage) in possessing only 6 thin rod-like external spines and a shell formed from a meshwork of interwoven bars forming angular meshes and covered by small spinules, whereas $P$. offerta displays a porous latticed shell with more than 12 external spines. It differs from the Upper Ordovician species P.? estonica Nazarov in possessing thinner, longer and less numerous outer spines and in its less massive shell structure. It differs from Silurian species $P$. stelcki and ?P. leeorum in its larger size (c. $200 \mu \mathrm{m}$ for ?P. leeorum, 70$135 \mu \mathrm{m}$ for $P$. stelcki), more angular mesh structure and the presence of interwoven bars.

Most Polyentactinia species are described from the Devonian to Permian interval. As concerns the Devonian species, P. spinulenta is easily distinguished from $P$. kossistekensis, $P$. rudihispida and $P$. propinga by its internal structure and number of primary spines (7-8 rays for $P$. kossistekensis; 7-10 rays for $P$. propinga and $P$. rudihispida). P. circumretia differs from $P$. spinulenta by having a 6- to 7-rayed point-centred spicule centrally located and bi- or trifurcated outer spines. $P$. spinulenta differs from $P$. polygonia, $P$. craticulata and $P$. leptosphaera in its larger size (90-180 $\mu \mathrm{m}$ in P. polygonia; $115-150 \mu \mathrm{m}$ in P. craticulata; 160 $240 \mu \mathrm{m}$ in $P$. leptosphaera). The shell structure of $P$. spinulenta also differs from $P$. invenusta and $P$. tenera, which display a thin and delicate shell structure constructed in a three-dimensional way as thick spongy tissue.

\section{Polyentactinia. sp. cf. P. spinulenta Pouille \& Danelian} (P1. 2, fig. 9)

Material. 2 specimens.

Description. Internal framework consists of an initial spicule formed of a very short median bar (about $8 \mu \mathrm{m}$ ) eccentrically located that may appear point-centred depending on orientation. Five primary rays emerge from the median bar and turn into thick rod-like outer spines outside the shell surface. Two primary rays are longer than the others and bear at their distal ends two long perpendicular whorled rays connected to the outer shell meshwork. Some of them may emerge from the shell surface as secondary spines. Simple apophyses can be present at the distal end of these whorled rays and be merged with the bars of the shell meshwork. The shell is formed of a loose meshwork of thick straight and curved bars interwoven in a disorderly manner or fused. Numerous simple or bi- to trifurcated spinules are present on the shell surface.

Dimensions ( $\mu \mathrm{m})$. Diameter of the shell: 330-365; length of the median bar: $c$. 8 ; thickness of the inner elements of the skeleton: up to 20 .

Remarks. This species differs from $P$. spinulenta in having much thicker primary rays, a thicker skeleton structure, larger dimension and in the presence of numerous spinules on the shell surface. It also differs from $P$. spinulenta in possessing whorled rays on only two primary spines and in having only five primary spines and a much shorter median bar. 
Polyentactinia sp. A

(P1. 2, figs 10a-10b)

Material. 1 specimen.

Description. Internal framework consists of an initial spicule formed of a long median bar (about $60 \mu \mathrm{m}$ ), eccentrically located, from which five (six?) primary rays originate. The primary rays are prolonged into thick rod-like straight outer spines. Two to three perpendicular whorled rays originate at the distal parts of each primary rays and fuse with the spherical skeleton. Some of them emerge from the shell surface as rod-like secondary spines. Apophyses branch from the primary spines to form an irregular spherical loose meshwork consisting of thick straight and curved bars interwoven in a disorderly manner or fused. Numerous simple or bi- to trifurcated spinules are present on the shell surface.

Dimensions $(\mu \mathrm{m})$. Diameter of the shell: 325-365; length of the median bar: about 60; thickness of the inner elements of the skeleton: up to 20 .

Remarks. This specimen differs from $P$. sp. cf. $P$. spinulenta in possessing up to three whorled rays on the primary spines and also in the larger size of the median bar.

\section{Polyentactinia sp. B}

(P1. 2, figs 11a-11c)

Material. 1 specimen.

Description. The outer shell displays an ovoid outline and is characterized by an intergrowth of strongly fused bars. The skeleton is very compact and made of thick elements. Eight to ten thick rod-like outer spines emerge from the shell surface and can bear small simple apophyses. Numerous thin and long spinules are present on one side of the shell surface. The internal framework is hidden except for a six-rayed point centred spicule visible from a wide opening.

Dimensions $(\mu \mathrm{m})$. Diameter of the shell: $282-335$; length of the outer spines: up to 122 .

Remarks. Internal framework remains uncertain as the inner structure of the shell is not entirely visible. The six-rayed point-centred spicule may be considered as the initial skeleton but none of the thick rod-like outer spine seems to be connected with the rays of this spicule. Therefore, a more detailed study of the inner-frame is needed to understand the internal structure. Polyentactinia sp. B outer shell structure clearly differs from all other Polyentactinia species in its characteristic intergrowth of strongly fused bars and the more developed long spinules covering the shell surface. This skeletal structure of Polyentactinia sp. B displays some affinities with the Silurian genus Palaeophippium but it differs from it by not showing a saddle-shaped internal spicule with apical and basal hemispheres.

Order Spumellaria Ehrenberg, 1875

Family Haplotaeniatidae (Won et al., 2002)
Genus Haplotaeniatum Nazarov \& Ormiston, 1993, emend. Won et al., 2002, emend. Jones \& Noble, 2006

Type species. Haplotaeniatum labyrintheum Nazarov \& Ormiston, 1993

$$
\text { Haplotaeniatum circulus n. sp. Pouille \& Danelian }
$$$$
\text { (P1. 3, figs 1-2b) }
$$

Derivation of name. From the Latin word 'circulus' meaning circle.

Diagnosis. Large spherical spongy outer shell, bearing long and massive rod-like spines, encapsulates 5-6 pseudospongy internal shells displaying a slightly spiraliform arrangement and a small latticed microsphere from which primary spines originate.

Holotype. Plate 3, figure 2 (USTL1142/061).

Material. 6 specimens.

Description. Haplotaeniatum formed of five to six irregularly circular pseudospongy latticed shells arranged in a slightly spiraliform fashion. Internal framework consists of a small, centrally located, latticed microsphere. Four visible primary rays originate from the microsphere. They are prolonged into long, massive rodlike spines (up to $350 \mu \mathrm{m}$ or more) outside the shell. Apophyses branch from the primary spines to form the different latticed shells surrounding the microsphere. A few apophyses can be irregularly placed giving the shell a spiraliform arrangement. The shells are connected together by thin beams, irregularly placed, forming a 'cellular-wall'. The shell layer forms numerous halfloops at the points where it is connected to the radial beams. The outermost shell is formed of a three-dimensional spongy meshwork which originates from two to three groups of apophyses branching from the primary spines. The outer shell displays a spherical shape. No secondary spines are present.

Dimensions $(\mu \mathrm{m})$. Diameter of the outer shell: $290-354$; of the microsphere: $40-52$; length of primary spines: up to 368 ; thickness of the cortical shell wall: $42-48$.

Remarks. This species differs from the Late Ordovician species of the genus Haplotaeniatum in its shell structure formed of four to five irregularly circular pseudospongy shells, its perfectly spherical shape and its large size (outer shell Ø: $104-170 \mu \mathrm{m}$ in H. spinatum; c. $145 \mu \mathrm{m}$ in H. fenestratum; 115-291(?) $\mu \mathrm{m}$ in H. prolatum; $180-230 \mu \mathrm{m}$ in $H$. ovatum). Externally, $H$. circulus may appear similar to $H$. ovatum when the latter displays a circular outline. However, $H$. circulus can still be easily distinguished from it by the presence of long thick rod-like outer spines and the absence of a pylome. $H$. circulus shows closer affinities with Lower Silurian species. It shares a similar shell structure with $H$. labyrintheum in the presence of three to five spiraliform shells united by means of transverse cross-beams. Both species share approximately the same size (outer shell Ø: $336-354 \mu \mathrm{m}$ in $H$. circulus; 296-354 $\mu \mathrm{m}$ in $H$. labyrintheum, microsphere Ø: $40-52 \mu \mathrm{m}$ in $H$. circulus; $38-43 \mu \mathrm{m}$ in $H$. labyrintheum) but $H$. circulus still differs from $H$. labyrintheum in having a centrally positioned microsphere, a thinner meshwork and very thin cross beams. H. circulus also differs from 


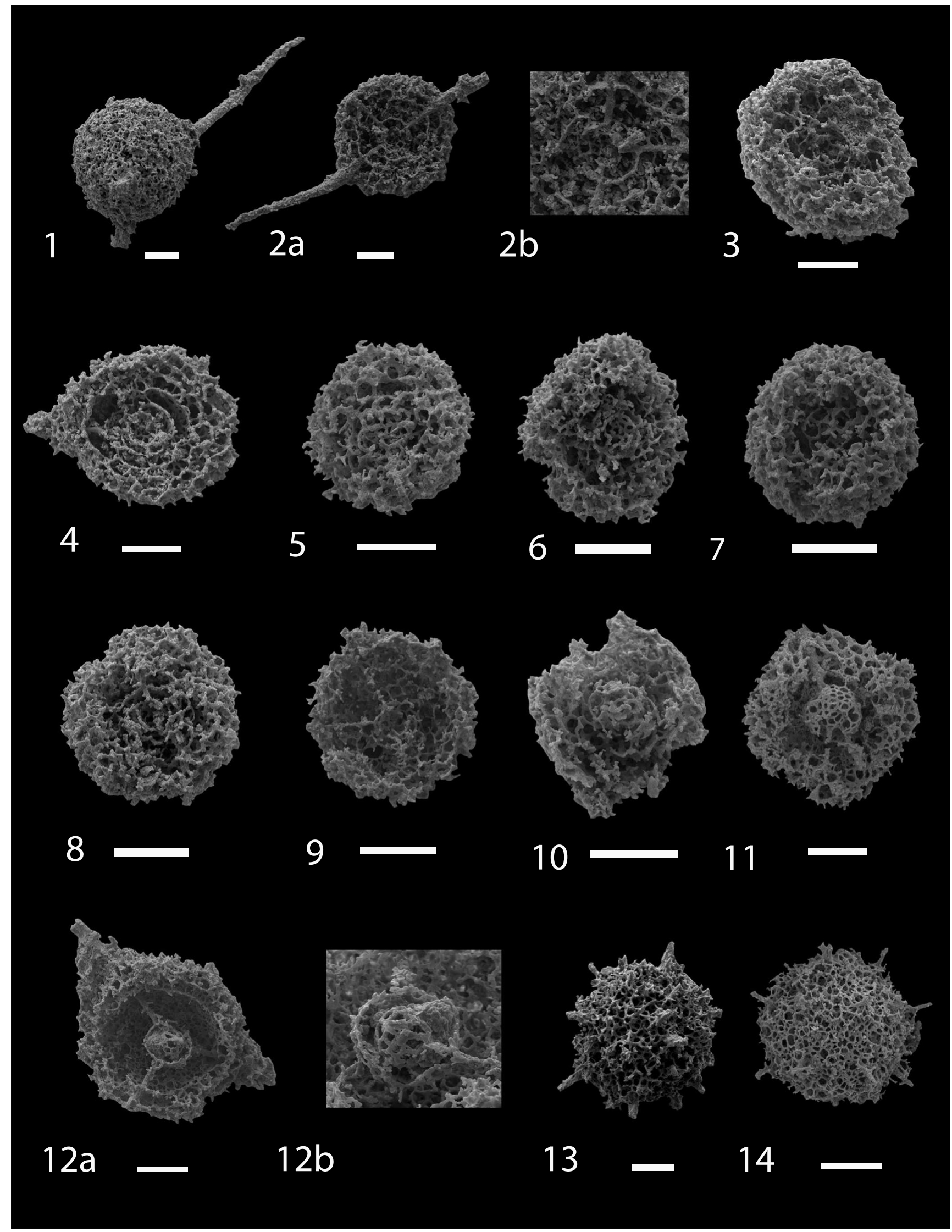


H. labyrintheum in the length of its primary spines (up to $368 \mu \mathrm{m}$ in $H$. circulus; up to $100 \mu \mathrm{m}$ in $H$. labyrintheum). However, this difference is certainly preservational as $H$. labyrintheum's spine length sensu MacDonald (2006) reaches $480 \mu \mathrm{m}$. H. circulus also displays structural similarities with $H$. cathenatum which possess four to five intermediate shells of an isometric form between the microsphere and outer shell. Our species differs from $H$. cathenatum, however, in having a more spherical shape, well-developed massive primary spines (spine length up to $368 \mu \mathrm{m}$ in $H$. circulus; up to $80 \mu \mathrm{m}$ in $H$. cathenatum) and in the absence of a pylome.

$H$. circulus also differs from $H$. primordialis? and $H$. tegimentum in its larger size, which is $194-208 \mu \mathrm{m}$ in $H$. primordialis? and $240-264 \mu \mathrm{m}$ in $H$. tegimentum, and in its well-developed outer spines (up to $40 \mu \mathrm{m}$ in $H$. primordialis?; up to $20 \mu \mathrm{m}$ in $H$. tegimentum). It also differs from $H$. tegimentum in the absence of half-closed shells and conical external spines and in possessing a centrally located microsphere.

\section{Haplotaeniatum sp. cf. H. circulus Pouille \& Danelian}

$$
\text { (Pl. 3, figs 3-4) }
$$

Material. 9 specimens.

Description. Shell consisting of a centrally located microsphere surrounded by four to five shells arranged in a spiraliform fashion. Shell layers are interconnected by small and irregularly placed beams. They display a cellular outline, forming numerous half-loops at the point where they are linked to the beams. The outermost shell is egg-shaped and formed of a thin spongy meshwork. At least two primary spines were observed to originate from the microsphere. Outer spines are thick and covered with spongy accretions that accentuate the ellipsoidal shape. No secondary spines are present.

Dimensions $(\mu \mathrm{m})$. Diameter of the outer shell: $240-358$; of the microsphere: $50-55$.

Remarks. In its shell structure this morphotype resembles H. circulus. However, it differs from it in its more accentuated spiraliform construction, in its ellipsoidal shape and its weakly developed primary spines. It also resembles $H$. labyrintheum, but it differs from it in possessing very thin radial beams, weakly developed primary spines, a larger, centrally located, microsphere (Ø: $38-43 \mu \mathrm{m}$ in H. labyrintheum) and more distinct layering.

Haplotaeniatum sp. cf. H. tegimentum (Nazarov in Nazarov \& Ormiston, 1993)

(P1. 3, figs 5-10)

cf. 1993 Haplotaeniatum tegimentum Nazarov in Nazarov \& Ormiston: 42; pl. 3, figs 14-16.

cf. 2000 Haplotaeniatum tegimentum (Nazarov in Nazarov \& Ormiston); Kurihara \& Sashida: 152; pl. 7, figs 1-13. cf. 2004 Haplotaeniatum tegimentum (Nazarov in Nazarov \& Ormiston); Kurihara: pl. 1, figs 1-2.

Material. 33 specimens.

Description. The internal framework consists of a microsphere surrounded by a complex meshwork of several latticed layers formed from curved to curled bars developed in a spiraliform way. The curled bars give rise to numerous small half-closed loops around the microsphere. No internal cavity appears to be individualized. The microsphere, which is not easily distinct, is, in general, centrally located. Rare beams are present. Three to four primary rays originate from this microsphere but they are rarely developed externally. The outer shell consists of a thick spongy, three-dimensional shell of variable thickness. It displays a spherical to subspherical outline.

Dimensions $(\boldsymbol{\mu m})$. Diameter of the outer shell: $220-280$; of the microsphere: $26-38$.

Remarks. Morphologically this species is very similar to H. tegimentum illustrated by Kurihara (2004), from which it differs in its centrally located microsphere and in the absence of any external spines. It differs from the co-occurring $H$. circulus and Haplotaeniatum sp. cf. $H$. circulus in its less distinct and less numerous internal shell layers, its thickest spongy outer shell and its denser layering structure formed of numerous small half-closed loops around the microsphere. It also differs in its smaller outer shell and smaller microsphere.

This taxon differs from the Upper Ordovician species of the genus Haplotaeniatum in its internal shell structure, its dense and thick three-dimensional spongy outer spherical shell and its large size (outer shell Ø: $104-170 \mu \mathrm{m}$ in H. spinatum; c. $145 \mu \mathrm{m}$ in $H$. fenestratum; 115-291(?) $\mu \mathrm{m}$ in $H$. prolatum; $180-230 \mu \mathrm{m}$ in $H$. ovatum). It is easily distinguished from $H$. ovatum by its more discernable internal layering and the absence of a pylome. It differs from $H$. labyrintheum and $H$. cathenatum in its smaller size (outer shell Ø: 296-354 $\mu \mathrm{m}$ in H. labyrintheum; 308-394 $\mu \mathrm{m}$ in $H$. cathenatum), in possessing fewer internal shell layers that are more densely constructed, forming numerous half-closed loops of a very small size around the microsphere and a thick spongy three-dimensional outer shell. It also differs from $H$. labyrintheum in possessing a centrally located microsphere, lacking rod-like external spines and a cellular wall, and from $H$. cathenatum in lacking a pylome and thin secondary spines. It differs from $H$. primordialis? in its larger size (outer shell Ø: 194-208 $\mu \mathrm{m}$ in $H$. primordialis?) and its denser internal shell structure. It differs from $H$. fissura in possessing a thick spongy outer shell with no distinct pores and the absence of a distinct gap between the microsphere and outer layers of the shell, the absence of a pylome and the weak development of primary spines. It differs from $H$. aperturatum and $H$. adobensis in lacking large pores on the outer shell surface, in having a more distinct internal spiraliform structure and lacking a pylome.

Explanation of Plate 3. Scanning electron micrographs of Spumellaria from sample 112 (Shundy Formation, North Balkhash Region, Kazakhstan). Scale bar $100 \mu \mathrm{m}$. figs 1-2b. Haplotaeniatum circulus n. sp. Danelian \& Pouille: 2a, holotype; 2b, magnified view of holotype displaying the microsphere and inner shell. figs 3-4. Haplotaeniatum sp. cf. H. circulus Pouille \& Danelian. figs 5-10. Haplotaeniatum sp. cf. H. tegimentum (Nazarov in Nazarov \& Ormiston). fig. 11. Haplotaeniatum? sp. A. figs 12a-b. Haplotaeniatum? giganteum n. sp. Pouille \& Danelian: 12a, holotype; 12b, magnified view of holotype displaying the microsphere and inner shell. fig. 13. Haplotaeniatum sp. B. fig. 14. Haplotaeniatum sp. C. 
Haplotaeniatum? giganteum n. sp. Pouille \& Danelian (P1. 3, figs 12a-12b)

Derivation of name. From the Latin word 'giganteus' meaning gigantic, huge.

Diagnosis. A large, spherical and spongy three-layered outer shell surrounds a much smaller inner latticed shell which encapsulates a microsphere. Six rod-like spines originate from the microsphere; they are covered proximally by numerous branching apophyses that join the outer shell.

Holotype. Plate 3, figure 12 (USTL1172/085).

Material. 5 specimens.

Description. Internal framework consists of a centrally located, latticed microsphere with uneven pores of variable size. This microsphere is encapsulated in a subspherical to oval inner latticed shell. Six primary rays originate in the microsphere and prolong outside the shell into thick rod-like spines. The inner shell is clearly separated from the outer shell by a large empty cavity. Small and simple apophyses, irregularly placed, can branch from the primary rays between the inner and outer shells. Some apophyses can join the inner shall surface. The outer framework consists of three thinly latticed oval shell layers closely interconnected by numerous short beams in the form of a three-layered wall arrangement. The outer shell surface displays a spongy aspect. Outer spines are covered at their proximal part with numerous apophyses branching to join the outer shell surface which contribute to give the shell a strong ellipsoidal shape.

Dimensions $(\mu \mathrm{m})$. Diameter of the outermost shell: 336-470; of the inner shell: 90-100; of the microsphere: 55-59; of the inner cavity separating outer and inner shells: 55-74; thickness of the outer structure: $50-62$; width of microsphere: 5-18.

Remarks. The internal part of H.? giganteum has been observed on only two specimens. This species is here assigned to the genus Haplotaeniatum based on its internal framework consisting of a microsphere. However, this is currently uncertain because it also displays some morphological affinities to the genus Syntagentactinia and it does not display any spiraliform arrangement as in Haplotaeniatum. On the contrary, it is formed of concentric shells, with internal and outer shells separated by a wide empty internal cavity, as in Syntagentactinia. In their emendation of the genus Haplotaeniatum, Won et al. (2002) included specimens that are definitely separated into outer and inner parts, but Jones \& Noble (2006) removed from it the forms possessing distinct inner and outer areas. Some Syntagentactinia possess a very small innermost sphere surrounding the primary spicule that can be mistaken for a microsphere (see S.? angulata Pouille \& Danelian n. sp. and Syntagentactinia? sp. A). However, as no primary rays have been observed to protrude inside the microsphere, as it stands this species is assigned to the genus Haplotaeniatum.

Haplotaeniatum? sp. A

(P1. 3, fig. 11)
Material. 1 specimen.

Description. Internal framework consists of a centrally located latticed microsphere from which six (?) primary rays originate. The microsphere is surrounded by a spherical inner latticed shell. The inner shell is clearly separated from the outer shell by a small empty cavity. Very thin and tiny beams emerge from the surface of the inner shell to connect the outer shell. The primary rays give rise to thick rod-like outer spines. Three to four groups of apophyses branch from the primary spines to form a thick threedimensional indistinctly layered spongy meshwork.

Dimensions $(\mu \mathrm{m})$. Diameter of the outermost shell: 319-325; of the inner shell: 99-100; of the microsphere: 53-54; of the inner cavity separating outer and inner shells: 28-41; thickness of the outer structure: $40-83$.

Remarks. This morphotype is formed of concentric shells, with the internal and outer shells separated by an empty internal cavity, as in Syntagentactinia. As no primary rays have been observed to protrude inside the microsphere, this species is tentatively assigned to the genus Haplotaeniatum. It differs from H.? giganteum n. sp. Pouille \& Danelian in its smaller size but also in possessing a smaller inner cavity of an irregular outline and a thick three-dimensional, indistinctly layered, spongy outer meshwork.

\section{Haplotaeniatum sp. B}

(P1. 3, fig. 13)

Material. 2 specimens.

Description. This specimen displays a dense three-dimensional mesh of bars which are interwoven in a disorderly manner to form a spherical shell. About 20 thick and short outer spines are irregularly placed on the shell surface. The outer shell displays a subspherical irregular outline. Inner structure is unknown.

Dimensions $(\boldsymbol{\mu m})$. Diameter of the outer shell: 313-320; thickness of the base of the outer spines: 20 to 25 .

Remarks. This species differs from other species of the genus Haplotaeniatum in the presence of numerous outer spines. A high number of outer spines is encountered most often in Oriundogutta which can possess from 8 to 20 external horns. However, Oriundogutta is distinguished by possessing a two-dimensional porous outer shell, whereas our morphotype displays a thick three-dimensional disorderly interwoven meshwork.

\section{Haplotaeniatum sp. C}

(P1. 3, fig. 14)

Material. 1 specimen.

Description. This specimen displays a roughly spherical test formed of a dense three-dimensional mesh of fine bars. It consists of several three-dimensionally interwoven latticed layers which give the shell a spongy appearance. There are about 20 thin short outer spines present. Apophyses may branch from the proximal 
part of the outer spines and merge into the outer shell meshwork. Internal structure is unknown.

Dimensions $(\mu \mathrm{m})$. Diameter of the outer shell: $238-255$; thickness of the base of the outer spines: 5 to 7 .

Remarks. This species differs from Haplotaeniatum sp. B in having a thinner and more delicate meshwork and thinner outer spines (thickness of the base of the outer spines: $20-25 \mu \mathrm{m}$ in Haplotaeniatum sp. B) and also in its smaller size (outer shell Ø: 313-320 $\mu \mathrm{m}$ in Haplotaeniatum sp. B).

\section{DISCUSSION}

Before our study, 30 radiolarian species and morphotypes were known from the upper Darriwilian-lowermost Sandbian Haplentactinia juncta-Inanigutta unica assemblage described by Nazarov \& Popov (1980). The new assemblage described in this paper presents an entirely new fauna, comprising 32 species and morphotypes (Fig. 3) recorded for the first time in the latest Darriwilian H. teretisculus graptolite zone.

The radiolarian assemblage found in our sample (112) may be correlated with Nazarov's assemblage from sample 553a, as they share six genera (Syntagentactinia, Kalimnasphaera, Polyentactinia, Inanihella, Inanibigutta and Haplentactinia) and one characteristic species (Haplentactinia juncta). However, in spite of their more-orless similar age, their high diversity and the number of common genera, the species composition of the two assemblages is very different (see Fig. 3). Indeed, despite their high diversity (9 genera and 32 species/morphotypes in sample 112; 10 genera and 30 species/morphotypes in sample 553a), the two assemblages share only 2 species (Haplentactinia juncta and Syntagentactinia biocculosa) and two closely related morphotypes (Kalimnasphaera aperta and Kalimnasphaera sp. aff. K. aperta, Inanihella bakanasensis and Inanihella sp. cf. I. bakanasensis).

Additionally, in spite of the high diversity of inaniguttids in sample 553a, our assemblage contains two genera (Haplotaeniatum and Triplococcus) which appear to be absent from the Haplentactinia juncta-Inanigutta unica assemblage. Moreover, these two taxa are very abundant in the 112 assemblage as they represent $52 \%$ of the total number of specimens present in the studied fauna. On the other hand the 112 assemblage lacks the genera Oriundogutta, Bissylentactinia and Ceratoikiscum?, which are present in the 553a assemblage.

This difference in assemblage structure may be due to the different age of the samples, as the radiolarians studied by Nazarov (in Nazarov \& Popov, 1980) from sample 553a appear to be slightly younger than our assemblage, as sample 553a was collected just below beds that contain the gracilis graptolites. Alternatively, the striking difference between the two assemblages may be due to palaeoenvironmental/palaeoceanographic or biofacies differences.

Our assemblage can be also correlated with the Inanihella bakanasensis-Triplococcus akzhala assemblage reported by Danelian \& Popov (2003) and Maletz et al. (2009), as it contains both of the characteristic species. It is worth remembering that it is also dominated by species of the genera Triplococcus and Inanihella, which comprise $59 \%$ of the entire fauna. However, Danelian \& Popov's (2003) and Maletz et al.'s (2009) assemblages are much less diverse (only 3 species described in samples P10 and A17 of

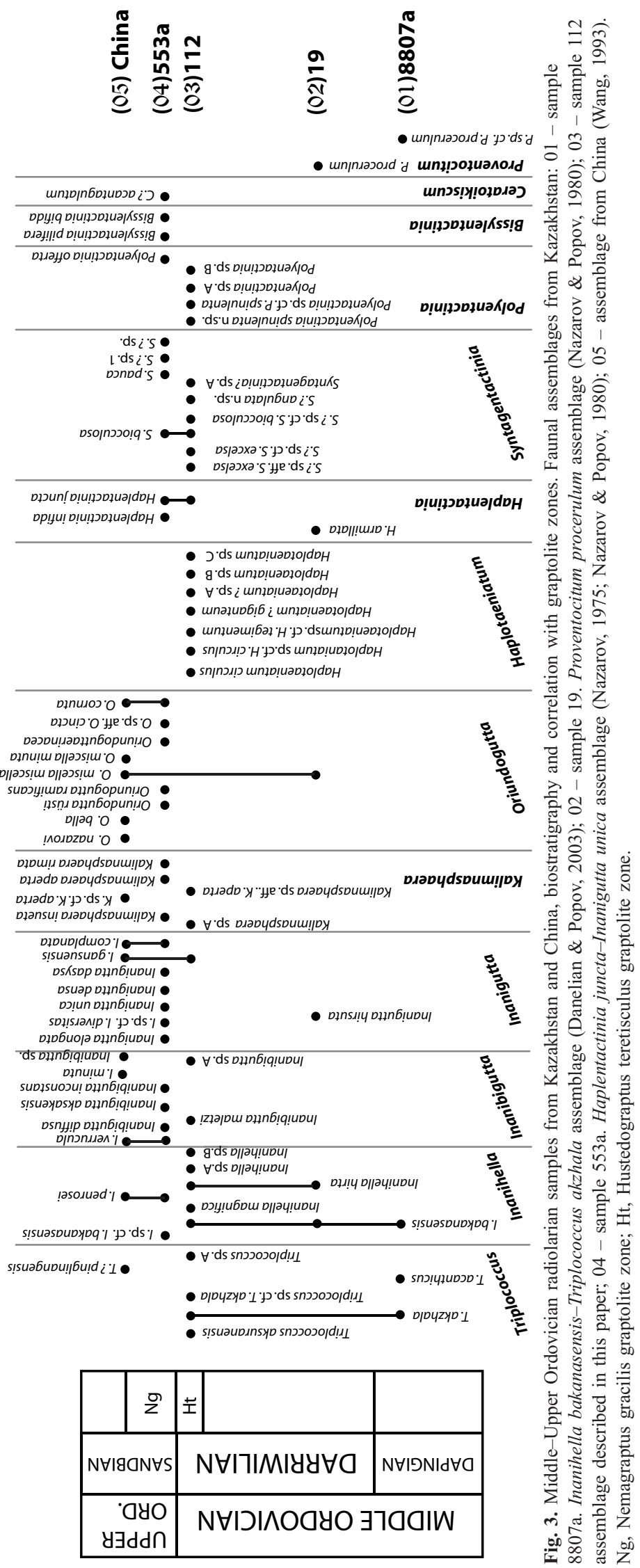


Maletz et al. (2009) and 4 species from sample 8807 as studied by Danelian \& Popov, 2003). Our assemblage, therefore, confirms that the two characteristic species of the Inanihella bakanasensisTriplococcus akzhala assemblage are not restricted to the earlymid-Darriwilian but also extend into the latest Darriwilian. Therefore, only the Proventocitum procerulum assemblage can be used to define the upper Dapingian-mid-Darriwilian interval.

The uppermost Darriwilian is characterized by the Haplentactinia juncta-Inanigutta unica assemblage. In the light of our new radiolarian assemblage from the Hustedograptus teretisculus Biozone, the uppermost Darriwilian can now be better defined by the cooccurrence of the genera Syntagentactinia, Kalimnasphaera, Inanibigutta, Protoceratoikiscum, which first occur from the Hustedograptus teretisculus Biozone, and the genera Triplococcus and Polyentactinia. It is also characterized by the absence of the genus Proventocitum. It displays the following characteristic species: Haplentactinia juncta, Inanigutta unica, Triplococcus aksuranensis, Kalimnasphaera aperta and Syntagentactinia biocculosa.

This study considerably improves our knowledge of radiolarian species occurring in the upper Darriwilian and provides a much better view of the radiolarian palaeobiodiversity during this critical interval from which well-studied planktonic groups (acritarchs, graptolites or chitinozoans) are known to reach their maximum diversity (Servais et al., 2008, 2010).

\section{CONCLUSION}

The description of an entirely new assemblage composed of 32 species and morphotypes, including six new species (four described here and two in Pouille et al., 2013) from the Shundy Formation of the Aksuran Mountain, enables us to improve our understanding of the palaeobiodiversity of upper Darriwilian Radiolaria. It also allows us to better define the age range and community structure of Middle Ordovician radiolarian assemblages, including the age range of previously recognized assemblages.

\section{ACKNOWLEDGEMENTS}

Lauren Pouille and Taniel Danelian acknowledge support from the University Lille 1 and the CNRS. Leonid Popov acknowledges logistical support from the National Museum of Wales. Philippe Recourt helped with the SEM. Constructive remarks by the two reviewers, Paulian Dumitrica and Jorg Maletz, and the handling editor, Claire Allen, improved the initial manuscript.

\section{Manuscript received 15 April 2014 \\ Manuscript accepted 15 April 2014 \\ Scientific editing by Claire Allen.}

\section{REFERENCES}

Aitchison, J.C. 1998. A lower Ordovician (Arenig) radiolarian fauna from the Ballantrae Complex, Scotland. Scottish Journal of Geology, 34: 73-81.

Apollonov, M. K., Zhemchuzhnikov, V. A. \& Dubinina, S. V. 1990. Ordovician of the north-western Balkhash area. Izvestiya Akademii Nauk Kazakhskoi SSR, Seriya Geologicheskaya, 3-16. [In Russian].

Buckman, S. \& Aitchison, J. 2001. Middle Ordovician (Llandeilan) radiolarians from West Junggar, Xinjiang, China. Micropaleontology, 47: 359-367.

Danelian, T. \& Clarkson, E.N.K. 1998. Middle Ordovician Radiolaria from bedded cherts of the Southern Uplands. Scottish Journal of Geology, 34: 133-137.
Danelian, T. \& Floyd, J. 2001. Progress in describing Ordovician siliceous biodiversity from the Southern Uplands (Scotland, U.K.). Transactions of the Royal Society of Edinburgh, Earth Sciences, 91: 489-498.

Danelian, T. \& Popov, L. 2003. Ordovician radiolarian biodiversity: insights based on new and revised data from Kazakhstan. Bulletin de la société géologique de France, 174: 325-335.

Danelian, T., Popov, L.E., Tolmacheva, T.Y., Ghobadipour, M.G., Neyevin, A.V. \& Mikolaichuk, A.V. 2011. Ordovician Radiolaria and conodonts from the Peri-Gondwanan Karatau-Naryn microplate (Sarydzhaz, eastern Kyrgyzstan). Geobios, 44: 587-599.

Danelian, T., Noble, P., Pouille, L. \& Maletz, J. 2013. Palaeogeographical distribution of Ordovician Radiolarian occzurrences: patterns, significance and limitations. In Harper, D.A.T. \& Servais, T. (Eds), Early Palaeozoic Biogeography and Palaeogeography. Geological Society, London, Memoirs, 38: 399-405.

Ehrenberg, C.G. 1875. Fortsetzung der mikrogeologischen Studien als Gesammt-Uebersichtder mikrokopischen Palaontologie gleichartig analysirter Gebirgsarten der Erde, mit specieller Rucksicht auf den Polycystinen-Mergel von Barbados. Königliche Akademie der Wissenschaften zu Berlin, Abhandlungen, Jahre: 1-225.

Foreman, H.P. 1963. Upper Devonian Radiolaria from the Huron member of the Ohio shale. Micropaleontology, 9: 267-304.

Fortey, R.A. \& Holdsworth, B.K. 1971. The oldest known well-preserved Radiolaria. Bollettino della Societa Paleontologia Italiana, 10, 35-41.

Gorka, H. 1994. Late Caradoc and early Ludlow Radiolaria from Baltic erratic boulders. Acta Palaeontologica Polonica, 32: 169-179.

Holdsworth, B.K. 1977. Paleozoic Radiolaria: Stratigraphic distribution in Atlantic borderlands. In Swain, F.M. (Ed), The Stratigraphic Micropaleontology of Atlantic Basin and Borderlands. Developments in Paleontology and Stratigraphy, 6: 167-184.

Jones, M.K. \& Noble, P.J. 2006. Sheinwoodian (uppermost Lower Silurian) Radiolaria from the Cape Phillips Formation, Nunavut, Canada. Micropaleontology, 52: 289-315.

Kozur, H. \& Mostler, H. 1982. Entactinaria subordo nov., a new radiolarian suborder. Institut für Geologie und Paläontologie, Innsbruck, 11: 399-414.

Kurihara, T. 2004. Silurian and Devonian radiolarian biostratigraphy of the Hida Gaien Belt, central Japan. Journal of the Geological Society, Japan, 110: 620-639.

Kurihara, T. \& Sashida, K. 2000. Early Silurian (Llandoverian) radiolarians from the Ise area of the Hida 'Gaien' Belt, central Japan. Paleontological Research, 4: 147-162.

MacDonald, E. 2006. Haplotaeniatumidae and Inaniguttidae (Radiolaria) from the lower Silurian of the Cape Phillips Formation, Cornwallis Island, Nunavut, Canada. Journal of Paleontology, 80:19-37.

Maletz, J. 2007. Overlooked and ignored: Radiolarians and their biostratigraphic potential in the Ordovician. Acta Palaeontologica Sinica, 46(suppl.): 291-297.

Maletz, J. 2011. Radiolarian skeletal structures and biostratigraphy in the early Palaeozoic (Cambrian-Ordovician). Palaeoworld, 20: 116-133.

Maletz, J. \& Bruton, D.L. 2008. The middle Ordovician Proventocitum procerulum radiolarian assemblage of Spitsbergen and its biostratigraphic correlation. Palaeontology, 51: 1181-1200.

Maletz, J., Albanesi, G.L. \& Voldman, G.G. 2009. Lower Darriwilian radiolarians from the Argentine Precordillera. Geobios, 42: 53-61.

Nazarov, B.B. 1975. Radiolaria of the Lower-Middle Paleozoic of Kazakhstan. Trudy Geologicheskogo Institua Akademii Nauk SSSR, 275: 1-203. [in Russian].

Nazarov, B.B. 1988. Paleozoic Radiolaria Practical manual of microfauna of the USSR, vol. 2. Nedra, Leningrad, 211-232. [In Russian]

Nazarov, B.B. \& Ormiston, A.R. 1993. New biostratigraphically important Paleozoic Radiolaria of Eurasia and North America. Micropaleontology Special Publication, 6: 22-60. 
Nazarov, B.B. \& Popov, L.E. 1980. Stratigraphy and fauna of the siliceous-carbonate sequence of the Ordovician of Kazakhstan; radiolarians and inarticulated brachiopods. Trudy Geologicheskogo Instituta Akademii Nauk SSSR, 331: 1-190. [In Russian].

Nazarov, B.B., Popov, L.E. \& Apollonov, M.K. 1977. Lower Paleozoic radiolarians of Kazakhstan. International Geology Review, 19: 913-920. [Translated from Nazarov, B. B., L. E. Popov \& M. K. Apollonov. 1975. Radiolyarii nizhnego paleozoya Kazakhstana. Izvestiya Akademii Nauk SSSR, Seriya Geologicheskaya, 96-105. [in Russian].]

Noble, P.J. \& Danelian, T. 2004. Radiolarians. In Webby, B.D., Paris, F., Droser, M.L. \& Percival, I.G. (Eds), The Great Ordovician Biodiversification Event. Columbia University Press, New York, 97-101.

Noble, P.J. \& Webby, B.D. 2009. Katian (Ordovician) radiolarians from the Malongulli Formation, New South Wales, Australia, a reexamination. Journal of Paleontology, 83: 548-561.

Pouille, L., Danelian, T., Ghobadi Pour, M. \& Popov, L. 2013. New and revised Inaniguttid Radiolaria and associated Trilobites from the upper
Darriwilian (Ordovician) Shundy Formation of Kazakhstan. Journal of Paleontology, 87: 1143-1159.

Servais, T., Lehnert, O., Li, J., Mullins, G.L., Munnecke, A., Nützel, A. \& Vecoli, M. 2008. The Ordovician Biodiversification: revolution in the oceanic trophic chain. Lethaia, 41: 99-109.

Servais, T., Owen, A.W., Harper, D.A.T., Kröger, B. \& Munnecke, A. 2010. The Great Ordovician Biodiversification Event (GOBE): The palaeoecological dimension. Palaeogeography, Palaeoclimatology, Palaeoecology, 294: 99-119.

Wang, Y. 1993. Middle Ordovician radiolarians from the Pingliang Formation of Gansu Province, China. Micropaleontology, Special Publication, 6: 98-114.

Webby, B.D., Droser, M.L. \& Paris, F. (Eds) 2004. The Great Ordovician Biodiversification Event. Columbia University Press, 484pp.

Won, M.Z., Blodgett, R.B. \& Nestor, V. 2002. Llandoverian (Early Silurian) radiolarians from the Road River Formation of EastCentral Alaska and the new family Haplotaeniatumidae. Journal of Paleontology, 76: 941-964. 
One of the largest integrated collections of online Earth science literature in the world
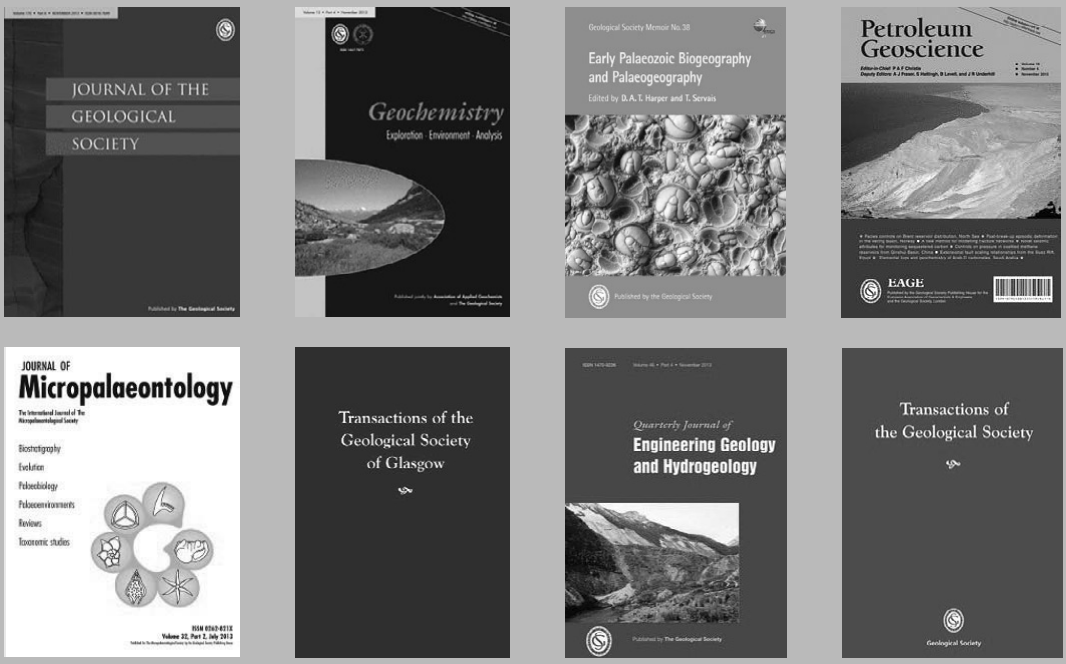

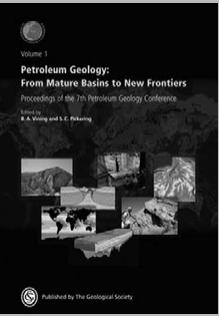

\section{What is the Lyell Collection?}

The Lyell Collection is an online collection comprising the Society's journal titles, Special Publications and key book series. Cutting edge science sits alongside important historical material, benefiting from the superb functionality offered by the online host, HighWire Press.

With 260,000 peer-reviewed pages, 26,000 articles and 1,000 volumes, the Lyell Collection is an invaluable tool for the researcher and student alike.

- Full text in HTML and PDF format

- Actively linking to cited references

- Free abstracts

- Free ETOC alerting

- Selected articles free online

- The Lyell Collection welcomes Open Access papers
- JGS, QJ, GEEA and PG offer specially-designed sites for those using mobile devices

- New: Transactions of the Edinburgh Geological Society and Transactions of the Geological Society of Glasgow

\section{Special Publication archives}

The first 300 volumes of the Geological Society's Special Publications Online Archive are available as a one-off purchase with perpetual access.

\section{The Geological Society}

The Geological Society of London was founded in 1807 and is the UK national society for geosciences. It is a global leader in Earth science publishing, dedicated to providing high-quality content and service throughout the world.

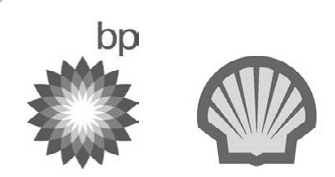

